\title{
Randomized Controlled Trial to Assess the Role of Raised Anal Pressures in the Pathogenesis of Symptomatic Early Hemorrhoids
}

\author{
Ashutosh Chauhan Shaji Thomas Prem Kumar Bishnoi Niladhar S. Hadke
}

Department of Surgery, Lady Hardinge Medical College, Shaheed Bhagat Singh Marg, New Delhi, India

\section{Key Words}

Hemorrhoids · Manometry, anal · Band ligation •

Sclerotherapy, injection

\begin{abstract}
Background: Increased maximum resting anal pressures (MRAP) have been found in patients with large prolapsed hemorrhoids undergoing hemorrhoidectomy, but their pathogenic role is controversial especially in view of the sphincteric damage that occurs with open and stapled procedures. This prospective randomized clinical trial was conducted to compare anal pressure changes in early symptomatic hemorrhoidal disease before and after successful treatment with band ligation or injection sclerotherapy, and to compare these pressures with those in normal asymptomatic controls. Methods: 32 patients with symptomatic grade II hemorrhoids were randomized to treatment with either band ligation or injection sclerotherapy. Anal manometry was done before treatment and 8 weeks after completion of treatment, and compared with 20 normal age-matched controls. Results: The pretreatment values in both study groups were similar to each other $\left(69.38 \mathrm{~cm} \mathrm{H}_{2} \mathrm{O}, 95 \% \mathrm{Cl} 58.67-80.08\right.$, vs. $67.75 \mathrm{~cm} \mathrm{H} \mathrm{H}_{2} \mathrm{O}, 95 \% \mathrm{Cl} 56.86-78.64 ; \mathrm{p}=0.790$ ), but were significantly higher ( $p=0.0001$ in both groups) than in the controls ( $\left.45.25 \mathrm{~cm} \mathrm{H}_{2} \mathrm{O}, 95 \% \mathrm{Cl} 38.36-52.14\right)$. After successful completion of treatment, there was a highly significant drop
\end{abstract}

\section{KARGER}

Fax +41 613061234 E-Mail karger@karger.ch www.karger.com
(C) 2007 S. Karger AG, Basel

0253-4886/07/0241-0028\$23.50/0

Accessible online at:

www.karger.com/dsu in the MRAP in both study groups $(p=0.0001$ in group $A$, and $p=0.001$ in group $B$ ) reaching normal values. Conclusions: Our study shows that even in early-stage hemorrhoids, the anal pressures are significantly raised, but after successful treatment with band ligation or injection sclerotherapy, these pressures return to normal, showing that they do not play a pathogenic role but are secondary to the congested hemorrhoidal cushions.

Copyright $\odot 2007$ S. Karger AG, Basel

\section{Introduction}

Hemorrhoids are one of the most common ailments to afflict mankind. Although many patients present with symptomatic disease, many do not and some never have any symptoms. Hence it becomes difficult to give any assessment of their prevalence. The incidence of piles apparently increases with age, and it seems likely that at least $50 \%$ of people over the age of 50 have some degree of hemorrhoid formation. Men seem to be affected roughly twice as frequently as women [1].

Hemorrhoidal disease is the consequence of distal displacement of the anal cushions, which are normal structures that play an important role in continence [2-4]. The causes of hemorrhoidal disease are unknown and constipation is blamed despite largely contrary evidence. The 
Table 1. Clinical features of patients

\begin{tabular}{lllll}
\hline & $\begin{array}{l}\text { Male/ } \\
\text { female }\end{array}$ & $\begin{array}{l}\text { Age } \\
\text { years }\end{array}$ & $\begin{array}{l}\text { Weight } \\
\mathrm{kg}\end{array}$ & $\begin{array}{l}\text { Duration of } \\
\text { symptoms, months }\end{array}$ \\
\hline Group A $(\mathrm{n}=16)$ & $10 / 6$ & $35.9(18-55)$ & $60.5(41-73.5)$ & $7(2-11.5)$ \\
Group B $(\mathrm{n}=16)$ & $11 / 5$ & $35.7(18-55)$ & $59.9(40-72.5)$ & $7.5(2-11)$ \\
\hline
\end{tabular}

The values are means with ranges given in parentheses.

most consistently demonstrated physiological abnormality is an increased maximum resting anal pressure (MRAP) [1]. However, most of these studies are on patients with large prolapsed hemorrhoids undergoing hemorrhoidectomy [5-8] where it becomes difficult to conclude if the raised MRAP plays any pathogenic role or is secondary to the large hemorrhoidal masses. Further, the use of anal dilators and retractors during stapled or open hemorrhoidectomy often results in anal sphincter injuries with a resultant postoperative decrease in MRAP $[9,10]$.

If a raised anal pressure could be implicated in hemorrhoidal etiology, then procedures to lower these pressures may play a part in the treatment of hemorrhoids.

The present study was undertaken at the Department of Surgery, Lady Hardinge Medical College, New Delhi, to examine the relationship of anal pressures to symptomatic early (grade II) hemorrhoidal disease, and whether successful band ligation or injection sclerotherapy done to manage these early hemorrhoids bring about any changes in anal pressures.

\section{Materials and Methods}

The present prospective, randomized, controlled study was conducted in the Department of Surgery, Lady Hardinge Medical College, New Delhi, after Institutional Ethics Committee approval. 32 consecutive adult patients with symptomatic grade II hemorrhoidal disease attending the surgical outpatient department entered the study after giving informed consent. The controls were 20 normal age-matched adults with no anorectal symptoms who were enrolled in the study to evaluate the normal resting anal pressure.

The patients $(n=32)$ were treated on an outpatient basis. They underwent a detailed clinical evaluation, which included rectal and proctoscopic examinations. Patients with other local anorectal pathologies, such as anal fissure, fistula in ano, rectal prolapse, and anorectal infections, were excluded. Patients with prolapsed hemorrhoids were also excluded. The patients were then randomized into the 2 treatment groups using a randomized block design. Patients in group A $(n=16)$ were subjected to band ligation - with the patients in the left lateral position, anal proctoscopy was done and the Barrons band ligator was used to apply 3-mm rubber bands over the pile masses. The patients in group $B(n=16)$ were treated by injection sclerotherapy - with the patients in the left lateral position, anal proctoscopy was done and an injection of $5 \%$ phenol in almond oil was made into the submucous coat of the bowel above the pile mass using a Gabriel syringe. In all patients, all pile masses were treated in a single session. Treatment was assessed after 3 weeks according to symptomatic relief (cessation of bleeding) and reduction in the pile mass to grade I or less on proctoscopy; treatment was repeated if required at this time.

Anal manometry was done at the first visit (before treatment) and 8 weeks after completion of treatment. Anal manometry was done using the Griffon model of the Albyn Medical Computer System (Scotland, UK) using water-perfused probes with remote sensors for pressure recording. The station pullout technique was used and the average MRAP was recorded. The pre- and post-treatment readings were compared with each other and with those of the agematched control group of 20 normal asymptomatic adults.

After successful completion of treatment, the patients were followed up after an interval of 8 weeks to assess symptomatic relief and for manometric assessments.

Analysis of variance was used as the mode of statistical analysis; paired and ordinary t tests were used to study the changes before and after treatment, and between the treatment groups.

\section{Observations and Results}

All 32 patients in the study had a history of bleeding per rectum and a history of prolapsed piles during defecation, which returned inside the anus as soon as straining was over. 14 patients complained of a whitish discharge which soiled the undergarments. 9 patients complained of bothersome pruritis in the anal region. 26 of the total of 32 patients also had a history of constipation. The 2 groups were comparable to each other for age, sex, weight and duration of symptoms (table 1). 3 patients in group $\mathrm{A}$ and 4 patients in group $\mathrm{B}$ required a second treatment 3 weeks after the first session. There were no treatment failures and no patient required operative treatment.

The median resting anal pressures in the age-matched control group $(\mathrm{n}=20)$ was $45.25 \mathrm{~cm} \mathrm{H}_{2} \mathrm{O}(95 \%$ CI 38.36 - 
Table 2. Comparison of pre- and post-treatment anal pressures $\left(\mathrm{cm} \mathrm{H}_{2} \mathrm{O}\right)$ in the study groups with those of controls

\begin{tabular}{|c|c|c|c|c|}
\hline \multirow[t]{2}{*}{ Controls $(n=20)$} & \multicolumn{2}{|l|}{ Group A $(n=16)$} & \multicolumn{2}{|l|}{ Group B $(n=16)$} \\
\hline & pre-treatment & post-treatment & pre-treatment & post-treatment \\
\hline $45.25(38.36-52.14)$ & $\begin{array}{l}69.38(58.67-80.08) \\
p=0.0001\end{array}$ & $\begin{array}{l}46.75(39.28-54.22) \\
p=0.328\end{array}$ & $\begin{array}{l}67.75(56.86-78.64) \\
p=0.0001\end{array}$ & $\begin{array}{l}47.75(40.03-55.47) \\
p=0.233\end{array}$ \\
\hline
\end{tabular}

The values are medians with $95 \% \mathrm{CI}$ in parentheses.

Table 3. Change in anal pressures $\left(\mathrm{cm} \mathrm{H}_{2} \mathrm{O}\right)$ in the study groups after treatment

\begin{tabular}{lll}
\hline & Group A $(\mathrm{n}=16)$ & Group B $(\mathrm{n}=16)$ \\
\hline Pre-treatment pressures & $69.38(58.67-80.08)$ & $67.75(56.86-78.64)$ \\
Post-treatment pressures & $46.75(39.28-54.22)$ & $47.75(40.03-55.47)$ \\
Significance (paired t-test) & $\mathrm{p}=0.0001$ & $\mathrm{p}=0.001$ \\
\hline
\end{tabular}

The values are medians with 95\% CI in parentheses.
52.14). As can be seen from table 2 , the pretreatment values in both the study groups were similar to each other (69.38 cm $\mathrm{H}_{2} \mathrm{O}, 95 \%$ CI $58.67-80.08$, vs. $67.75 \mathrm{~cm} \mathrm{H}_{2} \mathrm{O}$, $95 \%$ CI 56.86-78.64; $\mathrm{p}=0.790)$. However, the pretreatment anal pressures in both groups $\mathrm{A}$ and $\mathrm{B}$ were significantly higher than in the controls ( $\mathrm{p}=0.0001$ in both groups). This shows that even in early hemorrhoids, anal pressures are raised much above normal values.

Eight weeks after successful completion of treatment, there was a highly significant drop in the anal pressures in both the study groups ( $\mathrm{p}=0.0001$ in group $\mathrm{A}$, and $\mathrm{p}=$ 0.001 in group B; table 3 ). However, the final post-treatment values in both the study groups were similar to each other $\left(46.75 \mathrm{~cm} \mathrm{H}_{2} \mathrm{O}, 95 \%\right.$ CI $39.28-54.22$, vs. $47.75 \mathrm{~cm}$ $\mathrm{H}_{2} \mathrm{O}, 95 \%$ CI 40.03-55.47; $\mathrm{p}=0.836$ ). On comparing the post-treatment values of the 2 treatment groups with the normal controls, there was no significant difference $(\mathrm{p}=$ 0.328 in group $A$, and $p=0.233$ in group $B$ ). The pre- and post-treatment resting pressures for both study groups taken together $(\mathrm{n}=32)$ also showed a significant drop in the anal pressures to normal values after treatment (68.57 $\mathrm{cm} \mathrm{H}_{2} \mathrm{O}, 95 \%$ CI 57.77-79.36, vs. $47.25 \mathrm{~cm} \mathrm{H}_{2} \mathrm{O}, 95 \%$ CI $39.66-54.85 ; \mathrm{p}=0.0001)$. This shows that after successful treatment of the hemorrhoids, the raised anal pressures return to normal values.

\section{Discussion}

The anal cushions resemble erectile tissue in that they contain large blood spaces fed by an arteriole. In normal subjects they may help to preserve continence by forming an expansible anal seal; however, they can plug the anus, impairing defecation and causing straining [2-4].

A new concept regarding the nature of hemorrhoids has been defined, in which hemorrhoids have been considered to be the result of downward displacement of the vascular submucosal cushions of the anal canal [2]. When the connective tissue of the submucosa degenerates, the cushions lose their support and descend into the lumen of the anal canal. A low-fiber diet, constipation and repeated and prolonged straining may contribute to descent of the anal cushions. This may result in anal outlet stenosis, with a congesting effect on the vascular cushions, especially during defecation [11].

In many studies, a high anal pressure has been associated with hemorrhoids [11-14]; whether the higher sphincter pressure is the cause or result of hemorrhoids is still obscure. Hancock [15] suggested that overactivity of the anal sphincter might be important in the pathogenesis of high anal pressure and hemorrhoids. Shafik [14] stated that the higher pressure in the hemorrhoids was caused by a fibrous anorectal band which induced a high shearing force during straining, thus causing protrusion and bleeding of the hemorrhoids. 
Teramoto et al. [16] suggested that the increased basal pressure in hemorrhoids was caused by a state of tonic contraction of the external sphincter muscle, and as a result of the pressure from a hemorrhoidal mass rather than the cause of hemorrhoids. Histochemical examination of external anal sphincter biopsies taken during hemorrhoidectomy operations showed an increased proportion of type-1 muscular fibers, implying a state of increased tonic contractions of this muscle in such patients [16].

During defecation, both internal and external sphincters normally relax to facilitate expulsion of the stool. Under conditions of sphincter relaxation, the presence of dilated anal cushions would create anal resistance, which patients can only overcome by increasing intra-abdominal pressure [4]. It is generally assumed that the abnormally high anal pressures are caused by an increased tonic activity in the internal and the external anal sphincters [17]. Forcible dilatation of the anal canal to disrupt the muscle fibers reduces the sphincter pressure to normal $[11,17]$, but pressures are also reduced by removal of the anal cushions [13], suggesting perhaps that pressure in the vascular space may contribute to high anal pressures in patients with hemorrhoids.

Most of the studies on anal pressures in patients with hemorrhoids have been done in late-stage prolapsed hemorrhoids showing increased anal pressures before treatment, with a decrease in pressures after hemorrhoidectomy [5-8]. One study [18] showed no decrease in the high anal pressures after treatment with band ligation and postulated that high anal pressures are an etiologic component in the formation of hemorrhoids. Another study [19] showed that anal pressures were the same in patients and controls, with no reduction in anal pressures after hemorrhoidectomy, and internal sphincterotomy was not found to be useful. Sphincter anomalies have also been seen in up to $87.5 \%$ of patients with prolapsed piles, leading to the suspicion that high anal pressures may play a pathogenic role [8]. The postoperative assessment of anal pressures in these late-stage patients are further complicated by the fact that the internal sphincter is easily damaged by the use of the Parks anal dilator in open hemorrhoidectomy [10] and also by the circular anal dilator in stapled hemorrhoidectomy [9]. Anorectal surgery also leads to anal sphincter defects $[13,20]$. Although there are surprisingly few studies on early-stage hemorrhoids, these patients also show increased anal pressures $[4,21,22]$; however, they have not been followed up after successful treatment using non-operative methods in which anal sphincter function is not compromised.

Our study shows that even in patients with early-stage hemorrhoids, anal pressures are significantly raised. After successful treatment with band ligation or injection sclerotherapy, these high anal pressures return to normal, showing that they do not play a pathogenic role but are secondary to the congested hemorrhoidal cushions.

The possibility that the anal resistance in patients with hemorrhoids is related to the engorged hemorrhoids themselves and not to any concomitant increase in anal muscle tone reinforces the idea that the correct surgical approach is to reduce the vascular mass by injection, banding, electrocoagulation, cryotherapy or excision [6]. Internal sphincterotomy or manual dilatation to weaken the sphincter muscle are only logical if the tone in the muscle is causing engorgement by obstructing venous return.

\section{References}

1 Williams NS: Hemorrhoidal diseases; in Keighley MRB, Williams NS (eds): Surgery of the Anus, Rectum and Colon. London, Saunders, 1993, vol 1, pp 295-363.

$\checkmark 2$ Thompson WH: The nature of hemorrhoids. Br J Surg 1975;62:542-552.

- 3 Gibbons CP, Trowbridge EA, Bannister JJ, Read NW: The role of the anal cushions in maintaining continence. Lancet 1986; 1: 886-888.

4 Sun WM, Read NW, Shorthouse AJ: Hypertensive anal cushions as a cause of the high anal canal pressures in patients with hemorrhoids. Br J Surg 1990;77:458-462.
5 Ho YH, Tan M: Ambulatory anorectal manometric findings in patients before and after hemorrhoidectomy. Int $\mathrm{J}$ Colorectal Dis 1997;12:296-297.

-6 El-Gendi MA, Abdel-Baky N: Anorectal pressure in patients with symptomatic hemorrhoids. Dis Colon Rectum 1986;29:388-391.

7 Khalil KH, O’Bichere A, Sellu D: Randomized clinical trial of sutured versus stapled closed haemorrhoidectomy. Br J Surg 2000; 87:1352-1355.

8 Roe AM, Bartolo DC, Vellacott KD, LockeEdmunds J, Mortensen NJ: Submucosal versus ligation excision haemorrhoidectomy: a comparison of anal sensation, anal sphincter manometry and postoperative pain and function. Br J Surg 1987;74:948-951.
9 Ho YH, Seow-Choen F, Tsang C, Eu KW: Randomized trial assessing anal sphincter injuries after stapled haemorrhoidectomy. Br J Surg 2001;88:1449-1455.

10 van Tets WF, Kuijpers JH, Tran K, Mollen R, van Goor H: Influence of Park's anal retractor on anal sphincter pressures. Dis Colon Rectum 1997;40:1042-1045.

11 Hancock BD, Smith K: The internal sphincter and Lord's procedure for hemorrhoids. $\mathrm{Br}$ J Surg 1975;62:833-836.

12 Arabi Y, Alexander-Williams J, Keighley MR: Anal pressures in hemorrhoids and anal fissures. Am J Surg 1977;134:608-610. 
13 Read MG, Read NW, Haynes WG, Donnelly TC, Johnson AG: A prospective study of the effect of hemorrhoidectomy on sphincter function and fecal incontinence. Br J Surg 1982;69:396-398

14 Shafik A: The pathogenesis of hemorrhoids and their treatment by anorectal bandotomy. J Clin Gastroenterol 1984;6:129-137.

15 Hancock BD: Internal sphincter and the nature of hemorrhoids. Gut 1977;18:651-655.

-16 Teramoto T, Parks AG, Swash M: Hypertrophy of the external anal sphincter in hemorrhoids: a histometric study. Gut 1981;22:4548 .
7 Vellacott KD, Hardcastle JD: Is continued anal dilatation necessary after a Lords procedure for hemorrhoids? Br J Surg 1980;67: 658-659.

18 Deutsch AA, Moshkovitz M, Nudelman I, Dinari G, Reiss R: Anal pressure measurements in the study of hemorrhoid etiology and their relation to treatment. Dis Colon Rectum 1987;30:855-857.

19 Chen WS, Leu SY, Wang FM: The roles of hemorrhoidectomy and lateral internal sphincterotomy in the treatment of hemorrhoids - clinical and manometric study. Zhonghua Yi Xue Za Zhi (Taipei) 1989;43: 255-260.
20 Felt-Bersma RJ, van Baren R, Koorevaar M, Strijers RL, Cuesta MA: Unsuspected sphincter defects shown by anal endosonography after anorectal surgery. A prospective study. Dis Colon Rectum 1995;38:249-253.

21 Hiltunen KM, Matikainen M: Anal manometric findings in symptomatic hemorrhoids. Dis Colon Rectum 1985;28:807-809.

-22 Sun WM, Peck RJ, Shorthouse AJ, Read NW: Hemorrhoids are associated not with hypertrophy of the internal anal sphincter, but with hypertension of the anal cushions. Br J Surg 1992;79:592-594. 